\title{
Walled City of Lahore: An Analytical Study of Islamic Cities of Indian Subcontinent
}

\author{
Dr. Saima Gulzar
}

\begin{abstract}
Cities are increasingly regarded as the dynamic and constantly evolving entities; therefore their segregation into typical idealistic forms is not possible. However, Islamic cities represent special cultural, social and historical identity that separates their city environment from others based on their Islamic cultural traditions, generated urban morphology/ patterns. Lahore is the historic cultural hub of the Punjab region and the second largest city of Pakistan after Karachi. The city of Lahore has a long history and was known with different names/ characteristics in the historical accounts. The city of Lahore that rose to prominence under Muslim dominance is selected for the study of Islamic City's concept in the Indian subcontinent due to distinctive regional variations in comparison to other Islamic Cities in different parts of the world. This research paper is based on explorative and comparative analytical research methods for the identification of the Islamic cities characteristics in the city of Lahore.
\end{abstract}

Keywords-Indian subcontinent, Islamic, Lahore, Walled City

\section{INTRODUCTION}

Islam according to many scholars is defined as an urban religion that made particular emphasis on the form, design and planning of the cities to accommodate the socio-economic, cultural and political structures/ frameworks of the community, based on the principles of unity in multiplicity and harmonious wholeness of opposites [1], [2]. Cities have always been studied as geographical areas comprising of small or large land spaces occupied by the group of people (may or may not be with the same religion) and their dependence on each other. The key factors are the social, economic, political and natural that forms the basis for the development of any community [3]

Cities that were constructed during the spread of Islam spanned a wide area from the Atlantic to the Indian subcontinent. Despite the diversity of climate and indigenous culture, they have emerged with a unique structure. The main feature is the Greater Mosque (Jamia Masjid) built to express the religious commitment and as the central symbol of the Islamic City. The ordered spatial growth around the central Mosque comprising of commercial (bazaars), administrative (qazi/ ulama) and associated activities is also one of the significant features [4]. The segregation of public and private spaces is the key factor in the formation of roads networks and street patterns along with the accessibility and penetration structures. This further plays the decisive role in the physical urban form of the Islamic City. The distinction of private from the public sector of the city is for the provision of peace, quiet, intimacy and security to the inhabitants. The architectural style

Manuscript received Nov. 14, 2016.

Dr. Saima Gulzar is with the School of Architecture and Planning, University of Management and Technology, Lahore. mainly adopted for the exteriors are simple and plain as discussed by many researchers [5].

The Islamic city has always been built in line with the natural forces making optimized use of light, wind, water and other resources available. In the design and structural forms of the city, using such concepts as backyard, porch, covered and narrow streets, orchids etc. was meant to accommodate the climatic and geographic conditions governing the Muslim lives in the warmer regions of the world.

\section{WALLED CITY OF LAHORE}

The Walled City of Lahore lies on the historic trade route linking Central Asia to the Indian subcontinent. It also has a direct access to the Arabian Sea in the south (Fig. 1). Located on the location $31^{\circ}$ North Latitude and $74^{\circ}$ East Longitude, Lahore is the capital of the Punjab (the land of five rivers) famous for its fertile plains that produce cotton, rice and fruits in abundance since ancient times (Fig. 2). Like many historic cities Lahore is also comprised of old historic and new modern part that is the extensions developed with the passage of time [6]. The old historic core is one of the traditional cities built on elevated ground that rose to prominence during the Mughals and flourished as the Walled City of Lahore in the Indian subcontinent. The Walled City of Lahore is surrounded by 9 meters high wall with 13 gates.

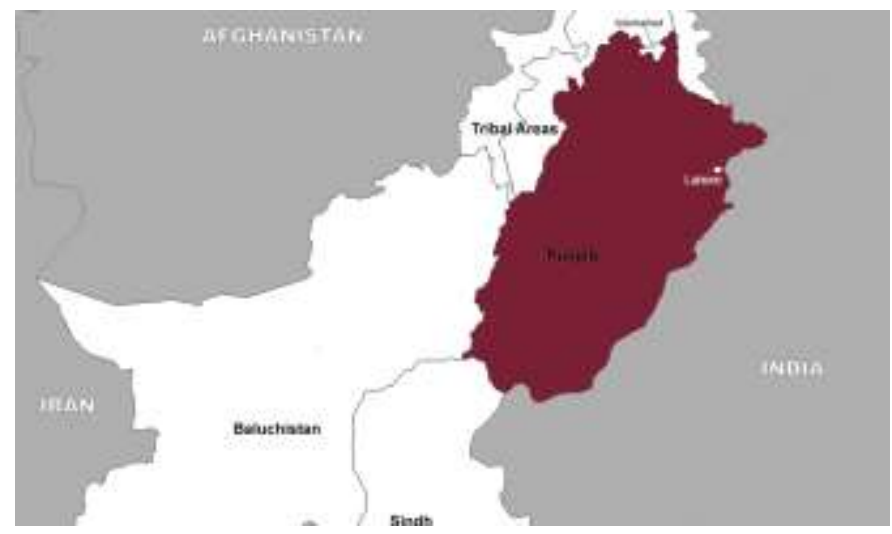

Fig. 1. Location Map of Pakistan 


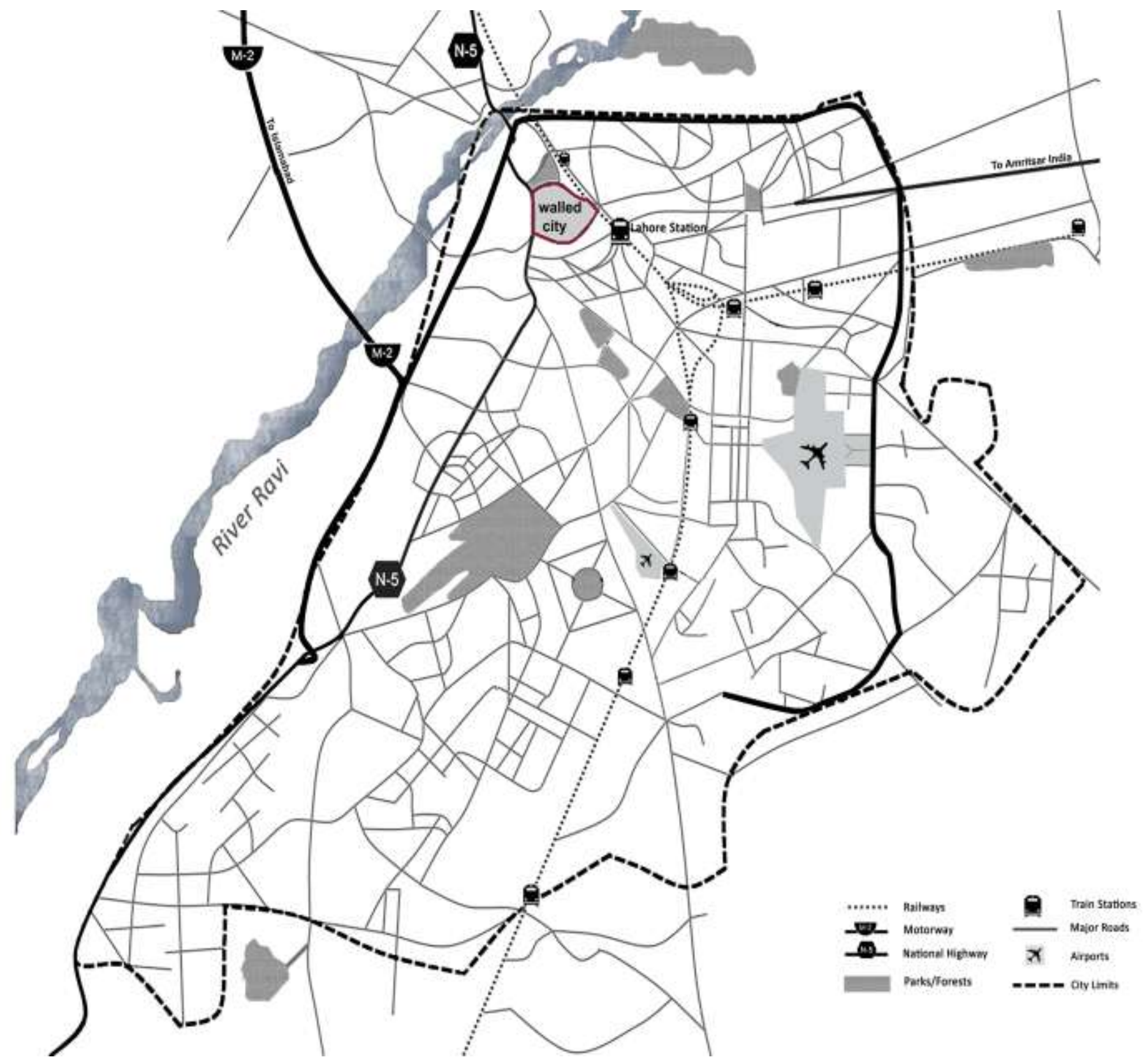

Fig. 2 Map of Lahore old historic Walled City and Modern Developments

\section{RESEARCH METHODOLOGY}

The integrated research methodology consisting of explorative and analytical studies of literature was applied for authenticity of the available documents [7]-[9]. The generated data was than evaluated for comparative studies to perform the Urban Morphological Analysis. This analytical method further evolved the characteristic features of the Islamic Cities with regional variations.

The Islamic Cities presented Coherent Urban System as a result of uniform legislative guidelines, identical socio-cultural framework created on Islamic principles, similar climatic conditions and construction techniques. The characteristic core urban pattern was found from Arabian Peninsula to westward across North Africa, to northwards over Asia Minor and to eastward across the Persian Empire throughout the vast geographic area with some regional variations. Thus "Walled City of Lahore" was selected as a case study to perform the comparative analysis for the identification of Islamic City characteristics in the Indian subcontinent [6].

\section{RESULTS AND DISCUSSIONS}

The Urban Morphological Analysis studied the urban forms and planning in comparative studies of characteristic features of the Islamic Cities in different parts of the world and resulted in the interpretation for the selected case study of the "Walled City of Lahore" (Table 1).

The studies revealed different concepts of "Islamic City" and defined them in three sections [4], [10]-[14]: 


\section{A. First Concept}

The cities defined in this section were mainly the conquered cities that maintained with their inherited historic urban traditions without any major changes.

\section{B. Second Concept}

The cities defined in this section were also the conquered cities and the new additions that transformed into Islamic cities with the application of Islamic design principles. These cities ancient structuring/ planning was modified and blended into the Islamic urban fabric displaying the characteristics of Islamic design philosophy.

\section{Third Concept}

The cities defined in this section were the new developments particularly planned and constructed on the Islamic City Concept. This model displayed a defining culture, social decorum, lifestyle, hierarchy etc. wrapped in the main contributing factor of being Islamic Community. Therefore the decisive and fundamental distinguishing character of the Islamic Cities is the Mosque in the center. This further forms the formal structure of the city governed by its location with accessory structures of madrasah, bazaar etc.

The main characteristic features concluded with the comparative analytical studies were categorized in the Table 1 [15]-[20]:

TABLE I: COMPARATIVE MORPHOLOGICAL ANALYSIS OF ISLAMIC CITIES AND WALLED CITY OF LAHORE

\begin{tabular}{|c|c|c|c|}
\hline \multicolumn{3}{|c|}{ Indicators for Order, Shape and Form in Islamic City } & Walled City of Lahore \\
\hline Natural Laws & $\begin{array}{l}\text { Natural Landscape, Topography, } \\
\text { Weather }\end{array}$ & $\begin{array}{l}\text { Courtyards, Terraces, Narrow } \\
\text { Streets, Gardens }\end{array}$ & $\begin{array}{l}\text { Pre-Islamic Origins, High Population Density } \\
\text { in some areas created differences }\end{array}$ \\
\hline Religious Beliefs & $\begin{array}{l}\text { Central Position of Mosque, Spatial and } \\
\text { Institutional Hierarchy, Segregation of } \\
\text { Public and Private }\end{array}$ & $\begin{array}{l}\text { Spatial Order in usage, } \\
\text { Accessibility, Narrow Streets, } \\
\text { Cul-de-sacs for separation of } \\
\text { Public and Private domains }\end{array}$ & Urban Fabric of Walled City \\
\hline Socio-Cultural & $\begin{array}{l}\text { Extended-Family Structures, Privacy, } \\
\text { Gender Separation, Strong Community } \\
\text { Interaction }\end{array}$ & $\begin{array}{l}\text { Land use, Main Streets, Public } \\
\text { Areas Location, Distinction of } \\
\text { Residential Quarters, } \\
\text { Built Form of the Courtyard } \\
\text { Houses, }\end{array}$ & $\begin{array}{l}\text { Primary Social Unit is Extended-Family } \\
\text { system, Segregation of Genders underline the } \\
\text { urban layouts }\end{array}$ \\
\hline Political & $\begin{array}{l}\text { Formal Leadership Governor and } \\
\text { Informal Religious Leadership Ulama, } \\
\text { Mufti }\end{array}$ & $\begin{array}{l}\text { Mosque is the religious, political } \\
\text { and intellectual center of the city }\end{array}$ & Formalized Civil Administration \\
\hline Economic & Islamic Economic Structure & $\begin{array}{l}\text { Location of Bazaars adjacent to } \\
\text { Mosques }\end{array}$ & $\begin{array}{l}\text { Traditional Bazaars but Hierarchical } \\
\text { arrangements followed the economic and } \\
\text { functional spatial distribution }\end{array}$ \\
\hline \multicolumn{3}{|c|}{ Morphological Characteristics of the Islamic City } & Walled City of Lahore \\
\hline Mosque Great & $\begin{array}{l}\text { Central Location, City Node, Referral } \\
\text { Axis, Accessory Buildings including } \\
\text { Madrasa }\end{array}$ & $\begin{array}{l}\text { A mosque is an axis of } \\
\text { connections, a center for activities } \\
\text { and it is a recognition factor of } \\
\text { residents living in urban areas. }\end{array}$ & $\begin{array}{l}\text { Wazir Khan Mosque as focal point, } \\
\text { surrounded by Bazaars, Badshahi Mosque } \\
\text { Greater and situated on raised platform }\end{array}$ \\
\hline Suqs/ Bazaars & $\begin{array}{l}\text { Adjacent to Mosque, Spatial } \\
\text { Distribution of Goods and Activities }\end{array}$ & $\begin{array}{l}\text { Bazaars on Main Axial Streets, } \\
\text { Central Space for Public } \\
\text { Activities, Social Services, } \\
\text { Hammams and Rest Places }\end{array}$ & $\begin{array}{l}\text { Spatial Distributions of Bazaars, Linear } \\
\text { Clusters along the Primary streets }\end{array}$ \\
\hline Citadel & $\begin{array}{l}\text { Higher Location for Governor, Walled } \\
\text { Structures, Offices, Guards, Residences }\end{array}$ & $\begin{array}{l}\text { Center of the City near Mosque or } \\
\text { Fortified Citadel on the periphery }\end{array}$ & $\begin{array}{l}\text { Strategic Location of Lahore Fort and } \\
\text { Badshahi Mosque and accessory buildings on } \\
\text { higher platform }\end{array}$ \\
\hline Residential Quarters & $\begin{array}{l}\text { Cluster of Households, Close Quarters, } \\
\text { Private Courtyards, Shops }\end{array}$ & $\begin{array}{l}\text { Located behind the Bazaars in } \\
\text { units, Private, Winding Streets, } \\
\text { Mosque small }\end{array}$ & $\begin{array}{l}\text { Residential areas built on privacy principles, } \\
\text { courtyards oriented, } 2-3 \text { stories }\end{array}$ \\
\hline Street Network & $\begin{array}{l}\text { Streets Network consisting of narrow } \\
\text { winding streets, Segregation of Public, } \\
\text { Private and Semi-Private }\end{array}$ & $\begin{array}{l}\text { Streets are narrow and winding, } \\
\text { covered mainly, no open spaces/ } \\
\text { public squares, main roads, } \\
\text { secondary through fares in } \\
\text { residential areas, cul-de-sacs }\end{array}$ & $\begin{array}{l}\text { Organic Growth, Limited accessibility, } \\
\text { Primary streets, secondary and residential } \\
\text { cul-de-sacs }\end{array}$ \\
\hline Boundary Wall & Well Built Wall for Defense with Gates & Defensive Imperatives & Walled City with 13 gates \\
\hline Outside & Cemeteries, Markets etc. & $\begin{array}{l}\text { Surrounded by the Major } \\
\text { Vehicular Road, Cemeteries, } \\
\text { Commercial Activities }\end{array}$ & Vehicular road, Commercial activities \\
\hline
\end{tabular}




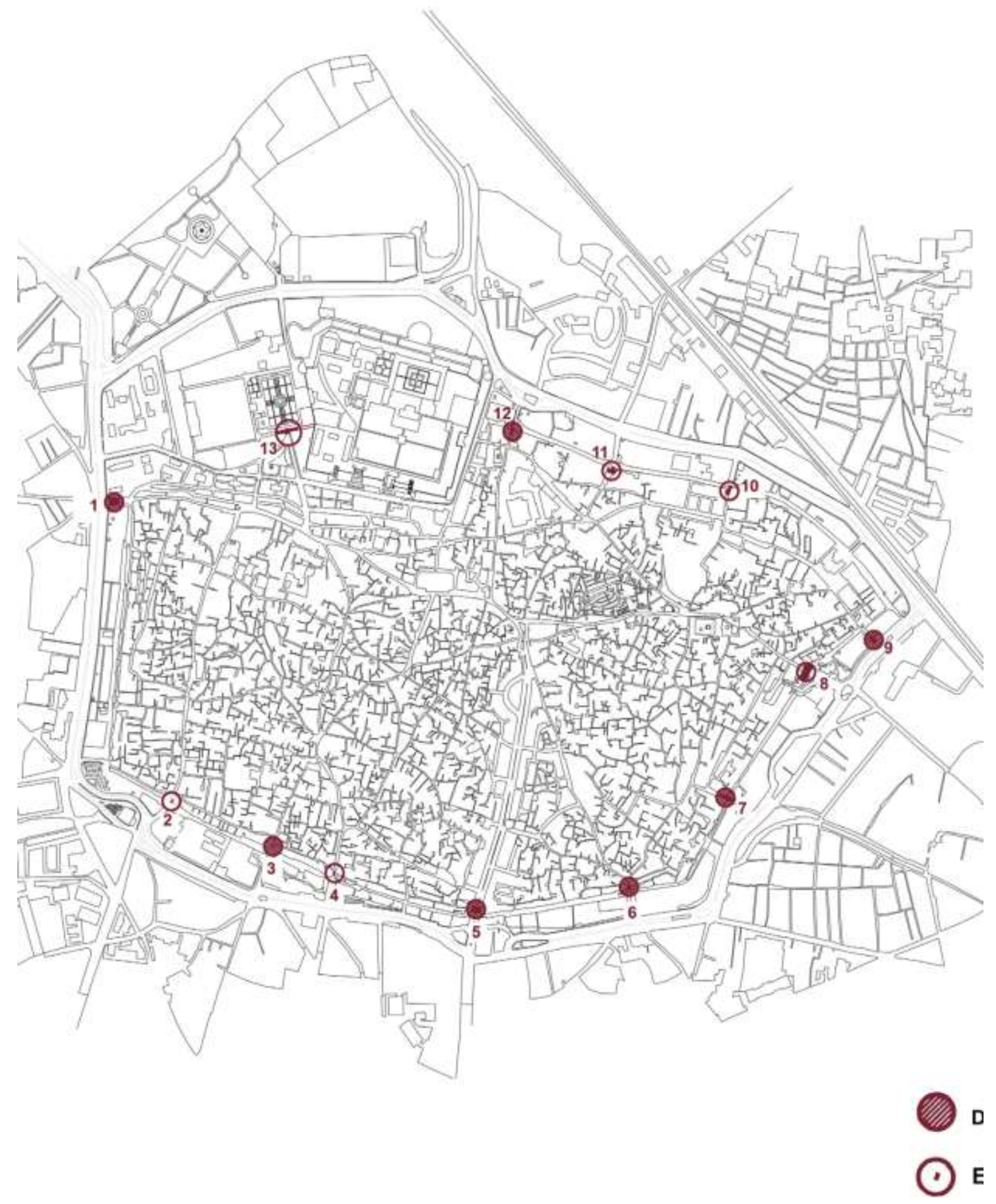

Fig. 3. Walled City of Lahore: the selected case study 


\section{References}

Number citations consecutively in square

\section{CONCLUSION}

The comparison of the "Walled City Lahore" physical urban fabric and planning characteristically follows the Islamic city urban morphological patterns. The street layout, boundary wall, gates, fortified palace along with the spatial distribution of Mosque, Bazaars and Residential quarters characteristically similar to the traditional Islamic cities in different parts of the world. The extensions outside the walled city core for the modern developments also followed the principles of Islamic cities to add them on the periphery and amalgamate into the old fabric. However the prototypical Islamic social structures and institutions were found with regional variation due to the strong non-Islamic cultural influences in the Indian subcontinent. The cohesive social organization has replaced the traditional Islamic city characteristic feature of social relationships and their interpretation. The traditional leadership structure of historic traditional Islamic cities was also disintegerated with the introduction of formalized civil administration as observed in Walled City of Lahore. The analytically observed sequential growth of the city from its earliest foundation reflected the heterogeneous character of the selected case study that matured under Islamic regimes.

\section{ACKNOWLEDGMENT}

The author would like to thank all the resource persons' who shared their valuable information during the preparation of this manuscript.

\section{REFERENCES}

[1] J. L. Abu-Lughod, "The İslâmic City--Historic Myth, İslâmic Essence, and Contemporary Relevance", International Journal of Middle East Studies, vol. 19, no. 2. pp. 155-176, May, 1987. https://doi.org/10.1017/S0020743800031822

[2] M. Nagi, "City characters in the texts of Islam" Fine Arts Journal no. 4 and 5, Art University, Tehran, 1998

[3] M. Weber, "Batı Şehri”, (tra. Fırat Oruç), Şehir ve Cemiyet, (edit. Ahmet Doğan), İz Yayıncılık, Istanbul 2000, pp. 131-167

[4] M. Hisham, "Traditional Islamic principles of built of environment" New York, Routledge Curzon, 2003

[5] C. Zeynep, "New Approaches to the "Non-Western" City", The Journal of the Society of Architectural Historians, vol. 58, no. 3, pp. 374 381, Sep., 1999.

[6] R. Ezdi," The dynamics of land use in Lahore Inner city: the case of Mochi Gate", M.Sc. thesis, National College of Arts, Islamabad, 2007.

[7] M. Kheir abadi, "Cities of Iran", translated by Hossein Hatami nejad and race Ezta Mafi, Published Nyka, Mashhad, 1990.

[8] N. Rabbat, "The Islamic City: Historicity and Abstraction", MIT, Department of Architecture, 2010., http://archnet.org/courses/islamiccity.Html

[9] H. Sarbanqly Sattar, "Urban design guidelines in the context of Tabriz traditional concept of sustainable development" Conference Proceedings, First Sustainable Development Management Conference in urban areas, Tabriz, Tabriz, 2002.

[10] A. S., Bagheri, "Theories about cities that territory of Islamic culture" Tehran: Amir Kabir Publications, 2007, pp. 84-92

[11] A. Hourani and S. M. Stern, eds., The Islamic City based on an Oxford University conference held in 1965, Philadelphia, 1970.

[12] S. Hakim Basim, "Islamic Arabic cities" Translation By: Malik Ahmadi, M. H, and Aghvami Mighaddam, A. Tehran: Publication Organization of the Ministry of Culture and Islamic Guidance, 2002

[13] G. von Grunebaum, "The Structure of the Muslim Town," Islam: Essays in the Nature and Growth of a Cultural Tradition, Memoir No. 81, The
American Anthropological Association (Ann Arbor, 1955). Reissued in second edition in London, 1961

[14] M. Cetin, "Contrasting perspectives on the Arab city" (Review Article), Urban Morphology, vol. 1, no. 15, pp. 79-84. 2011.

[15] S. K. Jayyusi, The City in the Islamic World, special editors, Renata Holod, Attilio Petruccioli and André Raymond. Leiden/Boston: Brill, 2008.

[16] A. Petruccioli, "After amnesia: learning from the Islamic Mediterranean urban fabric". Bari: ICAR. 2007.

[17] A. Raymonds," The great Arab cities in the 16th to 18th centuries: an introduction". New York/London: New York University Press. 1984

[18] A.S. Ibrahim, A.S., "Architectural Characteristics of The Islamic City", 2009, http://www.fountainmagazine.com/article.php?ARTICLEID=287

[19] R. Bharoto, 2012 (a)., Bazaar in Urban Open Space as Contain and Container Case study: Alun-alun Lama and Simpang Lima Semarang, Central Java, Indonesia. Procedia Social and Behavioral Sciences. www. Sciencedirect.com

[20] R. Bharoto and A. Malik 2012 (b). Between Colonial, Moslem, and Post-Independence Era, Which Layer of Urban Patterns Should Be Conserved?. Procedia Social and Behavioral Sciences. www. Sciencedirect.com

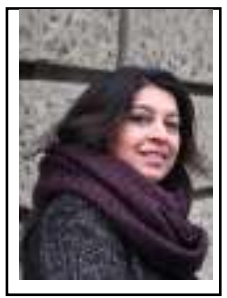

Dr. Saima Gulzar holds a position of Associate Professor in School of Architecture and Planning, University of Management and Technology, Lahore-Pakistan.

She has done her Postdoctoral Research from ETH-Zurich Switzerland in 2015 focusing Ornamental Techniques of 17 th century Mughal architecture in Pakistan.

She has published 9 research publications in international peer reviewed journals along with several posters and conference publications. 